PERANPESANTREN

\title{
SYAIKH ZAINUDDIN NAHDLATUL WATHAN \\ DALAM MENCERDASKAN MASYARAKAT \\ LOMBOK TIMUR
}

Oleh: Sirajuddin Ismail

\begin{abstract}
Abstrak
Penelitian ini berlokasi di Lombok Timur (tepatnya di Pesantren Syaikh Zainuddin Nahdlatul Watan). Penelitian menggunakan metode wawancara mendalam dan partispasi aktif. Penyusunan data dilakukan secara deskriptif kualitatif.

Hasil penelitian menunjukkan, bahwa di pondok pesantren ini terdapat lembaga pendidikan klasikal (sekolah) dan pendidikan kepesantrenan (ma'had dan ma'had Ali). Ma'had disebut pengajian umum dan dan Ma'had Ali disebut pengajian khusus.

Pembelajaran berlangsung sesuai dengan yang diharapkan karena dalam lembaga ini interaksi antara thullab dengan thullab, thullab dengan tuan guru berlangsung atas dasar keikhlasan sehingga menimbulkan rasa penghormatan, saling asah, asih dan asuh.

Proses pembelajaran menggunakan kurikulum khusus pondok pesantren, menggunakan sistem halaqah dengan metode sorogan, bandongan dan wetonan. dengan kitab klasik sebagai acuannya.
\end{abstract}

\section{PENDAHULUAN}

Pondok pesantren merupakan suatu institusi yang sangat penting bagi umat Islam. Lembaga ini memiliki potensi yang sangat besar sebagai lembaga pendidikan dan pengkaderan bagi generasi muda Islam dan membina masyarakat di sekitamya. Motivasi pendirian sebuah lembaga pendidikan pesantren, antara lain firman Allah SWT, tidak sepatutnya bagi orangorang mukim itu pergi semuanya (ke medan perang). Mengapa tidak pergi dari tiap golongan di antara mereka beberapa orang untuk memeprdalam pengetahuan mereka tentang agama. Dan memberi peringatan kepada kaumnya supaya mereka dapat menjaga dirinya. (Q.At Taubah, 122)

Sebagai lembaga pengembangan ilmu pengetahuan, pondok pesantren berfungsi mengembangkan ilmu pengetahuan keislaman, melakukan perubahan positif sehingga spektrumnya menjadi lebih luas, tidak hanya menyangkut pengembangan santri melalui pengetahuan keislaman tetapi juga menyangkut pengembangan ilmu pengetahuan lain, bahkan ada pondok 


\section{Sirajuddin Ismail}

pesantren yang memposisikan dirinya lebih maju dan modern dengan mengembangkan pengetahuan praktis (keterampilan). Terkadang ada pondok pesantren yang tidak mempertahankan sistem pendidikan tradisional sebagai ciri khas suatu pondok pesatren, mereka banyak mengadaptasi sistem pendidikan nasional. Di samping itu pondok pesantren dalam memberdayakan masyarakat lingkungannya dibidang ekonomi, pertanian, kesehatan dan lainlain.

Untuk menyukseskan program pondok pesantren, orientasi kemampuan dan peran patron kiai (tuan guru), ustaz dan para pembantunya sangat menentukan sistem pendidikan, disebabkan karena guru dan santri tinggal bersama dalam suatu tempat. Hal ini dikemukan pula oleh Moh Man (2003), bahwa sistem pendidikan berasrama (boarding school) adalah yang terbaik, guru sebagai pendidik dan para siswa hidup dalam satu lingkungan yang sama. Guru berperan sebagai pengajar (penyampai informasi, pembimbing, pembina, dan memberi teladan bagi para siswanya) dalam berbagai aspek kehidupan. Para siswa pun bisa menerima pelajaran, baik yang disampaikan secara formal maupun nonformal, sehingga proses belajar dan pembentukan kepribadian bagi siswa bisa berlangsung sepanjang hari. Metode ini sangat efektif dalam membentuk karakter siswa. Inilah hakikat dari metode pendidikan pesantren. Dengan demikian Tuan Guru tidak cukup hanya mengandalkan kharismatik dan pengetahuan keislamannya di dalam memimpin, akan tetapi harus memiliki kemampuan manajerial dan mampu menciptakan suasana yang konduktif baik intern maupun ekstern. Dampak positif dari metode ini pada komunitas muslim lebih meluas karena tidak terbatas pada santri, tetapi juga kepada masyarakat yang hidup di sekitar pondok pesantren, sehingga pondok pesantrenpun bisa berperan sebagai lokomotif dalam pembangunan peradaban.

Masalah pokok pada penelitian ini adalah efektivitas pendidikan kader ulama di Pondok Pesantern Syaikh Zainuddin Nahdlatul Wathan dan dari masalah pokok tersebut secara rinci di rumuskan masalah penelitian, yaitu apa dan bagaimana Pondok Pesantren Syaikh Zainuddin Nahdlatul Wathan? Bagaimana evektifitas pengkaderan ulama di Pondok Pesantren ini dan bagaimana dampaknya dalam kehidupan masyarakat?

Hasil penelitian ini bertujuan menggambarkan efektivitas Pengkaderan Ulama di Pondok Pesantren Syaikh Zainuddin Nahdlatul Wathan. Hasil penelitian ini diharapkan dapat dijadikan masukan bagi pemerintah, khususnya bagi Departemen Agama dan departemen terkait sebagai bahan penyusunan

arah kebijaksanaan program pembinaan dan pelayanan terutama dalam masalah pengkaderan ulama di masa depan. 
Para pakar mengemukakan rumusan pondok pesantren yaitu lembaga pendidikan Islam yang mempunyai figur sentral seorang Kiai, para ustaz sebagai dewan pengajar, masjid sebagai pusat kegiatan para santri belajar ilmu agama mempunyai sistem dan kurikulum serta asrama atau pondok tempat tinggal para santri. (Dja'far, 1990: 5). Pondok pesantren adalah lembaga pendidikan dan pengajaran agama Islam, umumnya dengan cara nonklasikal, seorang kiai mengajarkan ilmu agama Islam kepada santri berdasarkan kitab yang ditulis dalam bahasa Arab oleh ulama abad pertengahan dan para santri biasanya tinggal di pondok (asrama) dalam pesantren tersebut, (Sodjoko dkk, 1982:6)

Pondok pesantren adalah suatu lembaga pendidikan agama Islam yang tumbuh dan diakui oleh masyarakat sekitar dengan sistem asrama (kampus) santri menerima pendidikan agama melalui sistem pengajian atau madrasah yang sepenuhnya berada di bawah kedaulatan kepemimpinan seorang atau beberapa orang kiai dengan ciri khas yang bersifat kharismatik serta independen dalam segala hal. (Arifin, 1991) Pondok pesantren adalah suatu lembaga pendidikan Islam yang di dalamnya terdapat seorang kiai (pendidik) yang mengajar dan mendidik para santri (anak didik) dengan sarana masjid yang digunakan untuk menyelenggarakan pendidikan tersebut, serta didukung adanya pondok sebagai tempat tinggal para santri. (Muhaimin, 1993 : 299) Raharjo mengemukakan tentang karakteristik pondok pesantren, yaitu 1). Pondok pesantren tidak menggunakan batas umur bagi para santrinya. 2). tidak menerapkan batas waktu pendidikan, karena sistem pendidikan di pondok pesantren bersifat seumur hidup (life education). 3) siswa atau santrinya tidak dikelompokkan (klasifikasikan) dalam jenjang menurut kelompok usia sehingga siapa saja pada masyarakat yang ingin belajar bisa menjadi santri. 4) santri diberi kebebasan untuk tinggal (bermukim) di pesantren sampai kapanpun atau bermukim di situ selamanya dan dapat juga pindah mencari guru di tempat lain atau pulang ke tempat asal bila telah merasa cukup dan mampu mengembangkan diri sendiri. 5) Tidak memiliki jadwal ataupun peraturan administrasi yang tetap. 6) Metode pengajaran yang digunakan menggunakan sistem wetonan (halaqah). (1985:43).

Konsep tersebut menunjukkan bahwa pondok pesantren adalah lembaga pendidikan agama Islam yang di dalamnya terdapat elemen tertentu yaitu seorang kiai sebagai figur sentral, ustaz sebagai tenaga pengajar, masjid dan madrasah sebagai tempat berlangsungnya kegiatan pembelajaran, 


\section{Sirajuddin Ismail}

pondok sebagai asrama, kitab sebagai bahan ajar dan santri yang menerima pembelajaran dengan sistem halaqah (sorogan, bandongan dan wetonan).

Ulama biasa juga disebut kiai dan di Pulau Lombok dikenal dengan istilah tuan guru dan merupakan elemen paling sentral dari suatu pesantren. Pandangan ini dilatarbelakangi oleh peran kiai pada suatu pesantren dan realitas sejarah menujukkan bahwa kiai di samping sebagai seorang yang ahli dalam soal agama ia sekaligus merupakan pendiri, pengayom, guru dan juga merupakan orang tua bagi para santri yang menurut ilmu agama disebut pesantren. (Dhofier, $1984 ; 50$ )

Ulama, kiai atau tuan guru dalam istilah pondok pesantren adalah ulama karena ulama tidak bisa dipisahkan dengan pondok pesantren dan masyarakat, hubungan antara ulama dan umat Islam tampak perannya dalam pertumbuhan dan pengembangan masyarakat Islam, terlihat dalam masalah sosial, ekonomi, politik, dan kultur. Ulama menjadi figur terpandang dan terhormat dalam kehidupan masyarakat, dalam komunitas lokal, dominasi autoritas mereka semula terbatas pada pengurusan pesantren, masjid atau madrasah yang memberikan bimbingan, penuntun spiritual dan upacara keislaman dan pemimpin masyarakat bahkan ulama dikenal sebagai warasatul anbiya. Menurut Siddiqi, adalah tetesan tinta ulama sama halnya dengan tetesan darah syuhada, sirnanya ilmu pengetahuan diperlambangkan dengan punahnya ulama. (1996: 159)

Kerangka tersebut menunjukkan bahwa kalau dilihat antara pondok pesantren dan keberadaan ulama (tuan guru) memiliki hubungan simbiotik, artinya saling ketergantungan di dalam pencapaian tujuan, sadar atau tidak pondok pesantren sangat efektif sebagai tempat pembinaan kader ulama karena di dalamnya terdapat suatu lembaga pembinaan keislaman yang disebut ma'had 'Aly..

Penelitian ini bersifat kualitatif deskriptif yang menggambarkan halhal yang berhubungan dengan pondok Pesantren Syaikh Zainuddin Nahdlatul Wathan Anjani. Penelitian ini berlokasi di Kecamatan Suralaga Kabupaten Lombok Timur Provinsi Nusa Tenggara Barat.

Data yang diperoleh terdiri atas dua bagian: data primer dan data sekunder. Pengumpulan data primer dilakukan dengan teknik wawancara mendalam dengan tuan guru, para ustaz, dan pengelola pondok pesantren. Untuk melengkapi hasil wawancara, penulis melakukan pengamatan langsung seperti ikut serta dalam pengajian dan lain-lain. Hal-hal yang dijadikan sebagai obyek wawancara adalah seluruh hal yang berhubungan dengan pesantren, seperti sistem pengajaran, sistem pengelolaan pesantren 
dan sebagainya. Sedangkan data sekunder seperti kondisi geografi dan demografi diperoleh pada kantor instansi pemerintahan dan BPS setempat.

Setelah data terkumpul, dilakukan pengolahan sesuai dengan sifatnya.

Data yang diperoleh dari hasil wawancara dan pengamatan diolah secara kualitatif, sesuai dengan jenis data dan tujuan penelitian.

\section{PROFIL PONDOK PESANTREN}

\section{A. Sejarah Pesantren.}

Al Magfurullah Maulana Syaikh TGKH. Muhamad Zainuddin Abdul Majid memiliki dua orang isteri dan masing-masing isteri dikaruniai seorang putri. Pada isteri pertama lahir putri pertama bernama Sitti Rauhun dan putri kedua dari isteri kedua bernama Sitti Raihanun. TGKH. Muhammad Zainuddin Abdul Madjid biasa dipanggil oleh muridnya dengan Maulana Syaikh.

Ummi Hj. Sitti Raihanun Zainuddin Abdul Madjid, adalah tokoh pendiri Pondok Pesantren Syaikh TGKH. Muhammad Zainuddin Nahdlatul Wathan Anjani, yang terletak di Kabupaten Lombok Timur Nusa Tenggara Barat. Beliau adalah putri kedua dari Al Magfurullah Maulana Syaikh TGKH. Zainuddin pendiri madrasah Nahdlatul Wathan Diniyah Islamiyah (NWDI), Madrasah Nahdlatul Banat Diniayah Islamiyah (NBDI), Pondok Pesantren Darunnahdlatain Nahdlatul Wathan Pancor dan pendiri organisasai Nahdlatul Wathan. Raihanun lahir dari perkawinan Al Magfurullah Maulana Syaikh dengan Hj. Rahmatullah Hasan yang berasal dari Desa Janggik Kecamatan Terara Lombok Timur. Hj.Sitti Raihanun sering dipanggil olehjamaah dengan Ummi atau Ummuna atau Ummi Rehan atau Ummi Raihanun.

Ummi Hj.Sitti Raihanun berlatar belakang pendidikan Madrasah Nahdlatul Banat Diniyah Islamiyah (madrasah muallimin 6 tahun) Pancor dan Fakultas Tarbiyah IAIN Malang sampai tingkat III (baccaloreat), beliau hanya nyantri langsung pada orang tuannya Al Magfurullah Maulana Syaikh dan proses nyantri-nya. tidak terlalu banyak diketahui, tentu saja dengan cara khas seorang Tuan Guru atau Kiai dalam mendidik putra putrinya.

Nahdalatul Wathan didirikan 15 Jumadil Akhir 1372 H (01 Maret 1953 M) di Pancor Lombok Timur Nusa Tenggara Barat, didirikan oleh seorang ulama terkenal dan dikenal Al Magfurullah Maulana Syaikh TGKH. Muhammad Zainuddin Abdul Madjid. Sebagai organisasi kemasyarakatan Islam yang berkonsetrasi di bidang pendidikan, sosial, dan dakwah Islamiyah dalam dinamikanya terus berkembang sesuai dengan situasi dan kondisi 


\section{Sirajuddin Ismail}

perkembangan zaman. Sebagai organisasai kemasyarakatan yang eksistensinya diakui oleh semua pihak dalam melaksanakan visi dan misi dan semuanya dilakukan berdasarkan Anggaran Dasar dan Anggaran Rumah Tangga Nahdlatul Wathan. Pengurus tertinggi dikenal dengan Pengurus Besar dan pengurus terendah disebut pengurus ranting yang berkedudukan di tingkat kekadusan atau lingkungan. Pengurus organisasi ini dipilih sekali dalam lima tahun untuk tingkat Pengurus Besar sampai pengurus anak cabang (tingkat desa) dan sekali dalam tiga tahun untuk tingkat ranting. Selama hidup, pendirinya pernah mengadakan sembilan kali muktamar untuk memilih pengurus besar.

Pendiri Nahdlatul Wathan wafat pada 21 Oktober 1997 dan untuk kelangsungan kepemimpinan organisasi pasca wafatnya beliau, sesuai dengan Anggaran Dasar dan Angaran Rumah Tangga Nahdlatul Wathan maka dilaksanakan muktamar kesepuluh pada tanggal 24-26 Juli 1998 untuk memilih pemimpin organisasi dan terpilihlah secara demokratis $\mathrm{Ummi} \mathrm{Hj}$. Sitti Raehanun Zainuddin Abdul Madjid (putri bungsu pendirinya) sebagai Ketua Umum Pengurus Besar Nahdatul Wathan priode 1998 - 2003. Namun ada di antara warga Nahdlatul Wathan tidak menerima keputusan muktamar karena itu Pengurus Besar Nahdlatul Wathan terpaksa menghijrahkan pusat kegiatan dari Pancor ke Kalijaga termasuk lembaga pendidikan seperti Ma'had Darul Quran Wal Hadis (ma'had 'ali dalam organisasi Nahdlatul Wathan ), Institut Agama Islam Hamzanwadi dan Madrasah Aliyah.

Untuk mengurus lembaga pendidikan yang dihijrahkan maka pada 15 Ramadan 1419 H/26 Desember 1998 M didirikanlah Pondok Pesantren Syaikh Zainuddin Nahdlatul Wathan di Kalijaga Kecamatan Aikmel Lombok Timur dengan tokoh utama pendiri Ummi Hj. Sitti Raehanun Zainuddin Abdul Madjid (putri bungsu). Pemberian nama pondok pesantren dengan nama Syaikh Zainuddin Nahdlatul Wathan dimaksudkan untuk mengabadikan nama besar pendiri Nahdlatul Wathan sekaligus pondok pesantren ini dihajatkan sebagai kenang-kenangan bagi Al Magfurullah Maulana Syaikh, di samping mengikuti sunnah hasanah yang dicontohkan oleh Al Magfurullah untuk menghormati guru yang sangat dikagumi dan berjasa padanya dengan mendirikan pondok pesantren dengan nama gurunya tersebut, antara lain seperti pondok pesantren Al Hasanniyah Nahdlatul Wathan di Janggik sebagai kenangan bagi Al Magfurullah Maulana Syaikh TGKH. Hasan Muhammad Al Mahsyard, Pondok Pesantren Al Amin NW Pajeruk untuk Al Magfurullah Maulana Syaikh Amin Al Kutbi. 
Keberadaan Pondok Pesantren Syaikh Zainuddin di Kalijaga hanya bersifat sementara karena sudah terdapat Pondok Pesantren Darusshalihin Nahdlatul Wathan Kalijaga. Karena itu Pengurus Besar Nahdlatul Wathan mengadakan musyawarah dan memutuskan tiga lokasi sebagai calon untuk ditempati, yaitu di Desa Anjani, Desa Aikmel Utara dan Desa Kalijaga bagian Utara dan pada lokasi terakhir secara rasio tidak mungkin terpilih karena pada lokasi tersebut telah ada pondok pesantren Nahdlatul Wathan. Pada saat itu musyawirin belum bisa memutuskan di antara kedua lokasi tersebut karena sama-sama memiliki kelebihan dan kekurangan, maka mereka kembali pada prinsip para ulama untuk melakukan shalat istikharah bila terjadi perbedaan pendapat pada dua masalah. Maka Dewan Mustasyar Pengurus Besar Nahdlatul Wathan melakukan shalat istikhara dan sesuai dengan hasil istikharah maka musyawirin memutuskan lokasi Desa Anjani Kecamatan Suralaga kabupaten Lombok Timur sebagai lokasi yang tepat untuk pendirian Pondok Pesantren Syaikh Zainuddin Nahdlatul Wathan.

Keputusan musyawarah ini segera disosialisasikan kepada warga Nahdlatul Wathan dan secara tidak langsung mengharapkan pada mereka untuk beramal jariyah dalam pembebasan tanah dan pembangunan pondok pesantren tersebut. Keputusan ini disambut dengan antusias oleh semua pihak terutama warga Nahdlatul Wathan. Sebagai wujud dari kepedulian khusus warga Nahdlatul Wathan, maka Juli 1999 mampu membebaskan tanah seluas $0.73 \mathrm{Ha}$ di Desa Anjani dengan harga Rp. 146.000.000,- (seratus empat puluh enamjuta rupiah) dan pada April 2005 berhasil membebaskan lagi tanah seluas 17 hektar, 35 are. Pondok pesantren ini direncanakankan dibangun di atas tanah seluas $33 \mathrm{Ha}$, peletakan batu pertama pembangan pondok pesantren Syaik Zainuddin Nahdlatul Wathan dilaksanakan pada 9 Dzulhijjah 1419 H/15 Maret $2000 \mathrm{M}$.

Pada tahun ajaran 1999/2000 dibangun empat lembaga pendidikan, yaitu Madrasah Tsanawiyah Mu'allimin Nahdlatul Wathan, Madrasah Tsanawiyah Mu'allimat Nahdlatul Wathan, Aliyah Mu'allimin Nahdlatul Wathan, dan Madrasah Aliyah Mu'allimat Nahdlatul Wathan.

Lembaga pendidikan yang baru didirikan ini pada awalnya melakukan pembelajaran (numpang) di Pondok Pesantren Darushalihin Nahdlatul Wathan Kalijaga dan berlangsung hingga 26 Maret 2001. Pada tahun 2005 lembaga pendidikan yang dikelola oleh Pondok Pesantren Syaikh Zainuddin Nahdlatul Wathan Anjani terdiri atas 12 jenjang pendidikan mulai dari tingkat taman kanak-kanak sampai pada sekolah tinggi. Kegiatan pendidikan di pondok pesantren ini dimulai pada 1 Muharam 1422 H/26 Maret 2001 dan 
pada saat itu pula semua lembaga pendidikan yang menumpang di Pondok Pesantren Darushalihin Kalijaga secara resmi pindah di Pondok Pesantren Syaikh Zainuddin Nahdlatul Wathan Anjani di Desa Anjani Lombok Timur.

\section{B. Visi dan Misi.}

Visi: visi dari pondok pesantren Anjani ini adalah sebagai pusat kajian Islam dan teknologi di Kawasan Timur Indonesia dengan pendekatan tradisional dan modern untuk mencetak kader pembangunan yang menguasai ilmu pengetahuan dan teknologi, berakhlak mulia, mandiri dan beramal shaleh.

Misi: misi pondok pesatren Anjani ini adalah untuk mendirikan berbagai jenis lembaga pendidikan, mengadakan pendidikan, pengajaran, penelitian, pengkajian, pelatihan, memberdayakan perekonomian dengan pendekatan pemberian keterampilan kepada para santri dan masyarakat sekitar.

\section{Keadaan Pesantren.}

Lokasi Pondok Pesantren Syaikh Zainuddin Nahdlatul Wathan Anjani terletak di Desa Anjani Kecamatan Suralaga Kabupaten Lombok Timur.

Pondok pesantren ini memiliki sarana dan prasarana untuk menunjang kegiatan pendidikan, administrasi, yaitu antara lain berupa 52 ruangan belajar, 12 ruangan guru, perpustakaan, 1.645 buah kursi, aula, 14 unit komputer, 14 buah almari, 47 buah papan tulis, 9 stel kursi tamu, 2 OHP, 01 buah mesin las, 8 buah mesin jahit, sebuah studio radio, wartel, 47 kamar asrama putri, 65 ruangan kamar asrama putra, sebuah masjid, aula dan 7 kamar untuk tamu. Saat ini sementara berlangsung pembangunan berbagai fasilitas yang diperlukan dalam menunjang berbagai kegiatan termasuk proses pembelajaran.

Untuk kelancaran berbagai kegiatan kepesantrenan diperlukan dana yang cukup besar, baik untuk kegiatan operasional maupun untuk pembangunan. Biaya operasional diperoleh dari SPP, sumbangan awal tahun dari para santri dan dari usaha ekonomi pondok pesantren. Sedangkan dana pembangunan diperoleh dari amal jariyah warga Nahdlatul Wathan, donatur dan dari bantuan pemerintah. Sedangkan sumberdaya ekonomi yang merupakan usaha mandiri dari pondok pesantren ini berupa studio radio amatir, koperasi, toko, dan wartel.

Lembaga pendidikan yang dikelola Pondok Pesantren Syaikh Zainuddin NW Anjani terdiri atas 12 lembaga pendidikan, yaitu taman kanak- 
kanak, madrasah ibtidaiyah, Madrasah Tsanawiyah Mu'allimin, Madrasah Mu'allimat, SMP, Madrasah Aliyah Mu'allimin, Madrasah Aliy ah Mu'allimat, SMA, SMK, Ma'had Darul Qur'an wal Hadis, Institut Agama Islam Hamzanwadi NW, serta Sekolah Tinggi Manajemen Informatika dan Komputer (STMIK) Syaik Zainuddin NW.

Pondok pesantren ini mengasuh 5.152 santri, mereka mengikuti pendidikan formal pada lembaga pendidikan formal yang dibina oleh pesantren, para santri di samping mengikuti pendidikan formal juga mereka berkewajiban untuk mengikuti kegiatan pondok pesantren, yaitu mengikuti kegiatan pengajian ilmu keislaman dengan pendekatan tradisional, yaitu dengan cara sorogan, bandongan, dan wetonan (halaqah). Para santri yang mengikuti pendidikan berasal dari berbagai daerah, disamping dari Nusa Tenggara Barat, juga mereka berasal dari Bali, NTT, DKI, Batam, Sulawesi dan Kalimantan.

Pondok Pesantren Anjani diasuh oleh 267 orang dengan kualifikasi tuan guru, ustaz, guru, dosen dan tata usaha, mereka adalah luaran sekolah tinggi, 10 (sepuluh) orang di antara mereka adalah bantuan pemerintah Nusa Tenggara Barat (PNS guru) dari Departemen Agama.

\section{PROGRAM PENDIDIKAN KADER ULAMA}

\section{A. Pendidikan kader.}

Ide dasar yang memotivasi pendirian sebuah lembaga pendidikan pondok pesantren yang diberi nama Pondok Pesantren Syaikh Zainuddin Nahdlatul Wathan didasarkan atas kebutuhan komunitas Sasak di Anjani Lombok Timur. Walaupun mereka pada saat itu telah menganut Islam, tetapi masih diliputi kebodohan dan keterbelakangan terutama di bidang ubudiyah. Oleh sebab itu pemerhati komunitas Sasak Al Magfurullah Maulana Syaikh TGKH. Muhamad Zainuddin Abdul Madjid, sangat prihatin atas keadaan yang terjadi dalam masyarakat, sehingga beliau berusaha mengentaskan masyarakatnya dengan mengacu pada salah satu Firman Allah SWT: tidak sepatutnya bagi seorang Mukmin itu pergi semuanya (ke medan perang). Mengapa tidak pergi bagi tiap-tiap golongan di antara mereka beberapa orang untuk memperdalam pengetahuan agama dan untuk memberi peringatan kepada kaumnya apa bila mereka telah kembali kepadanya, supaya mereka itu dapat menjaga dirinya.(Q- Attaubah,122) 


\section{Sirajuddin Ismail}

Komunitas Sasak di Pulau Lombok masih sangat lemah bila dilihat pada intensitas keberagamaannya terutama di dalam memahami dan menghayati ajaran Islam sebagai suatu landasan spiritual dalam kehidupannya. Hal ini diperkuat oleh Abidin, bahwa pengetahuan keagamaan masyarakat SaSak masih terbatas pada kemampuan membaca Alquran, menghafal surat al Fatihah dan sedikit dari surat pendek dalam Alquran yang harus dibaca dalam shalat dan apa bila seseorang sudah bisa membaca satu zuz dari Alquran maka disebut ustaz dan apa bila sudah bisa membaca Alquran secara menyeluruh ( $30 \mathrm{juz}$ ) dengan fasih maka sudah bisa menjabat qadi atau penghulu di desanya. (1979)

Di samping itu, dalam komunitas Sasak dikenal Islam Wetu Tellu (Islam tiga waktu), yaitu suatu komunitas Islam yang mengaktualisasikan doktrin Islam diluar tuntunan Islam yang sesungguhnya. Komunitas ini mengaku Islam namun praktik ajarannya berbeda dengan ajaran Islam, yaitu melakukan ibadah terutama shalat mereka serahkan urusannya kepada kiai, selama kiai terebut bertugas di masjid sebagai marbot, sedangkan kaumnya hanya berkewajiban untuk melakukan upacara ritual kegamaan, seperti membaca kitab Al Barzanji dan upacara lingkran hidup lainnya (lahir, kawin, dan mati), karena pentingnya upacara ini maka harus dilakukan "dengan uapacara seremonial. Mereka mengerjakan ibadah puasa selama tiga hari, yaitu pada awal, pertengahan dan pada akhir bulan Ramadan (bulan puasa).

Hal itu menunjukan bahwa Al Magfurullah Maulana Syaikh TGKH. Muhamad Zainuddin Abdul Madjid berusaha untuk membebaskan umatnya (komunitas Sasak) di Lombok yang terkebelakang dan terbelenggu oleh kebodohan dari segi ajaran Islam sehingga mereka dikenal dalam ilmu antropologi sebagai masyarakat yang menganut kepercayaan. Mereka mengaku sebagai seorang muslim tetapi kearifan lokal juga dianggapnya sebagai ajaran Islam.

\section{Dinamika Pesantren.}

Pondok pesantren yang diidentifikasi sebagai lembaga pendidikan' Islam yang paling awal di Indonesia dan dianggap sebagai adaptasi Islam terhadap lembaga sejenis yang sudah ada sejak priode pra Islam, yaitu pada masa Hindu Budha. Pondok pesantren adalah suatu bentuk lembaga pendidikan khas Indonesia yang sebagian besar dipengaruhi oleh orangorang Islam. Pesantren lebih tua dari Islam karena bersumber dari tradisi penghormatan santri kepada guru, tata hubungan antara keduanya yang tidak didasarkan dengan materi, sifat pengajaran yang murni agama dan 
pemberian tanah oleh masyarakat (pemerintah) kepada guru. Oleh sebab itu secara historis pondok pesantren tidak hanya mengandung makna keislaman, akan tetapi sekaligus keaslian khas Indonesia.

Pondok pesantren sebagai lembaga yang bergerak dibidang pendidikan. Zaini mengemukakan, bahwa dalam pondok pesantren diselenggarakan kegiatan yang berdimensi; 1) Sebagai lembaga yang berorientasi kepada pembetukan watak atau pembinaan sikap mental.2)Sebagai lembaga yang menyelenggarakan kegiatan keilmuan, artinya pondok pesantren mengandung nilai keislaman sebagai konsep dan pelaksanaannya dalam memahami realitas kehidupan; 3) Sebagai lembaga yang di dalamnya terkandung nilai alamiah dan latihan tertentu sebagai usaha meningkatkan harkat dan mutu kemanusiaan. (1994: 94).

Pondok Pesantren Syaikh Zainuddin NW Anjani menerapkan model pendidikan tradisional dengan sistem halaqah dengan metode sorogan, bandongan dan wetonan. Thullab dan thullabah yang tinggal dalam pondok pendidikannya tidak dibatasi pada proses pembelajaran dan terintegrasi dalam kontek kehidupan pondok pesantren, seperi melaksanakan kegiatan peribadatan dan perilaku lain berdasarkan keteladanan serta tanggung jawab tuan guru. Pondok pesantren dan semua fasilitasnya adalah milik tuan guru. Namun demikian kehidupan di pondok pesantren, baik tuan guru, pembantu-pembatunya maupun para santrinya berciri pedesaan, sementara gaya kepemimpinan kharismatik paternalistik dan cenderung otoriter. Kombinasi kepemimpinan seperti itu menyebabkan pondok pesantren mempunyai pengaruh yang kuat terhadap masyarakat sekitar, bahkan pengaruhnya melampaui batas wilayah administratif pemerintahan lokal dengan pendirian pendidikan Nahdlatul Wathan oleh luaran pondok pesantren Nahdlatul Wathan walaupun secara organisatoris ada hubungan langsung dengan Nahdlatul Wathan Pusat Di Lombok Timur (bukan cabang), pendirian pendidikan NW atas dasar moralitas karena mereka luaran dari pondok pesantren NW, antara lain seperti pondok pesantren yang terdapat di Kalimantan dan Sulawesi. Tetapi adajuga luaran pondok pesantren Nahdatul Wathan mendirikan pondok pesantren/madrasah, walaupun tidak tergantung pada organisasi Nahdatul Wathan.

Dalam pondok pesantren dikembangkan dua sistem pembelajaran, yaitu sistem madrasah dan ma'had. Sistem madrasah menggunakan dua kurikulum, yaitu kurikulum Depertemen Agama dan kurikulum Departemen Pendidikan Nasional (Depdiknas). Di dalam perkembangannya, pondok pesantren telah berkembang dimulai pada dasawarsa tahun 1920-an melalui 


\section{Sirajuddin Ismail}

sistem pembelajaran dan kurikulum yang baru dengan sistem madrasah (klasikal) dan berupa ilmu pengetahuan umum. Sistem pendidikan ini pada mulanya diperkenalkan olch pondok pesantren di Jawa dan Sumatera pada abad ke 20 biasa disebut sistem madrasi, santri terpisah perkelas sesuai dengan jenjang pendidikannya, waktu pembelajarannyajelas diperkenalkan apa yang disebut sertifikat (ijazah).

Perkembangan sistem pendidikan dan kurikulum berimplikasi pada perkembangan struktur fisik yang sederhana sampai pada pola struktur fisik yang beragam. Tidak lagi hanya terdiri atas pesantren, masjid, rumah kiai dan pondok, tetapi mencakup di dalamnya bangunan madrasah, sekolah umum, ruangan keterampilan, sarana olahraga, gedung pertemuan, dapur umum, ruang makan, kantor, koperasi, dan toko.

Hal tersebut menunjukan bahwa pondok pesantren mengalami dinamika di dalam perjalanan searah dengan perkembangan situasi dan kondisi masyarakat dan pengaruh ilmu pengetahuan dan teknologi yang melejat dengan pesat. Hal ini terjadi pula pada pondok pesantren Syaikh Zainuddin Nahdlatul Wathan Anjani, yaitu mereka mengelola 12 lembaga pendidikan, baik pendidikan kepesatrenan maupun pendidikan umum, yaitu taman kanak-kanak, madrasah Ibtidaiyah, Madrasah Tsanawiyah Mu'allimin, Madrasah Tsanawiyah Mu'allimat, SMP, Aliyah Mu'allimin, Aliyah Mu'allimat, SMA, SMK, Ma'had Darul Quran Wal Hadis (ma'had Ali), Institut Agama Islam Hamzan Wadi Nahdatul Wathan dan Sekolah Tinggi Manajemen Informatika dan Komputer (STMIK) Syaikh Zainuddin NW.

Perlu dikemukakan bahwa Pondok Pesantren Syaikh Zainuddin NW berbeda dengan pondok pesantren lain termasuk pondok pesantren di Nusa Tenggara Barat yang pada umumnya dikenal tertutup dengan aturan yang cukup ketat, namun di pondok pesantren ini tergolong pondok pesantren terbuka, hal ini disebabkan karena 1) Letaknya tidak terpisah dengan pemukiman penduduk, tanpa sekat atau tembok pembatas. 2) Santrinya ada yang tinggal di pondok dan ada pula yang tinggal di luar (pemukiman penduduk sekitar). Begitu pula para tuan guru, ustaz yang dipercaya sebagai pembina dan pengasuh, mereka bebas tinggal di luar lingkungan pondok pesantren.

Tujuan pondok pesantren ini dengan model terbuka menurut salah seorang informan, yaitu memberi peluang kepada para santri untuk mencari pengalaman di luar pondok pesantren agar mereka berkembang secara alami, tetapi mereka berkewajiban mengikuti pengajian umum, keterbatasan fasilitas pemondokan dalam pesantren, memberikan peluang pada santri agar dapat 
berperan aktif dalam masyarakat untuk mengamalkan dan mengembangkan syariat Islam.

Perlu dikemukakan bahwa pondok Pesantren Anjani menganut sistem terbuka tetapi ma'had dikelola secara khusus karena; 1) mereka harus menempati suatu tempat tertentu. 2) tempat yang tenang. 3) memiliki aturan yang ketat. 4) mendapat kordinasi yang ketat dari seorang yang diberi amanah sebagai kepala pondok (wali pondok), 5) setiap waktu shalat dilakukan secara berjamaah.

Semua ma'had yang dikelola oleh pondok pesantren Anjani, bisa dibedakan mana yang merupakan pendidikan umum dan mana berupa pendidikan Islam (ma'had), kenyataan dilapangan menunjukan bahwa pondok pesantren Anjani membina tujuh ma'had dan satu Ma'had All

\section{B. Program Pendidikan.}

\section{Pendidikan Sekolah.}

Empat lembaga pendidikan yang pertama didirikan pada tahun 1999, yaitu MadrasahTsanawiyah Mu'allimin, Tsanawiyah Mu'allimat, Madrasah Aliyah Mu'allimin dan Aliyah Mu'allimat. Pendirian pendidikan terus berlanjut, tahun 2001 mendirikan SMA dan STMIK Syaihk Zainuddin. Th.2002 mendirikan SMP, Th.2003 mendirikan taman kanak-kanak, Th.2004 mendirikan SMK. Th.2005 mendirikan Madrasah Ibtidaiyah. Kegiatan Pembelajaran pada pendidikan formal berlangsung pada pagi hari untuk sekolah/madrasah dan Ma'hadAly, sesuai dengan ketentuan dari Mendiknas termasuk kurikulumnya, sedangkan madrasah dan Institut Agama Islam HAMZAN WADI menggunakan kurikulum Departemen Agama. Untuk Perguruan Tinggi perkuliahannya dilakukan pada sore dan malam hari.

Kalau diperhatikan bahwa semua pendidikan madrasi dalam pondok pesantren Anjani secara tidak langsung merupakan pengkaderan ulama hanya saja pendidikan agamanya sangat sedikit dan tidak bisa diharapkan pada jenjang itu menjadi kader ulama, karena lembaga sebagai pengkaderan ulama akan nampak terlihat pada ma'had dan ma'had All

\section{Pendidikan Kepesantrenan (Ma'had)}

Pendidikan yang dikemukakan disini adalah pendidikan kepesantrenan yang dikenal dengan ma'had. Sebelum mengemukakan program pembelajaran pada Ma'had Aly, maka dikemukakan tentang penerimaan 
thullab dan thullabah dengan segala pensyaratan administrasi, mereka juga harus bersedia membawa selembar tikar dan sebuah bantal dan digundul (laki-laki) pada saat bai 'at (pengukuhan) dan pada saat itu pula seorang di antara orang tua thullab mewak'ili orang tua calon thullab mengucapkan penyerahan (semacam ijab qabul) dalam suatu upacara yang disebut zakral hauliyah yang dihadiri oleh semua unsur pondok pesantren, Tuan Guru, amidul (dekan), ustaz, pembina yang disebut ngurisang atau selapanan (bahasa Jawa), yaitu dilakukan pencukuran massal yang dilakukan oleh Tuan Guru pada salah seorang thullab (kepalanya dicukur gundul) secara simbolis, sedangkan yang lainnya dilakukan diluar arena upacara dilakukan oleh siapa saja.

Upacara ini dimulai dengan membaca allahumma bariklahu waftah alaihi fatwal arifin dan diakhiri dengan suara rahasia, artinya ya Allah limpahkan padanya keberkahan dan bukakanlah pintu ilmu baginya. Hakikatnya membersihkan akhlak mereka untuk menerima suatu ilmu yang mulia, yaitu ilmu keislaman. Perlu dikemukakan bahwa dalam upacara ini calon thullabah tidak digundul seperti calon thullab, hanya kepala mereka diketuk dengan gagang gunting satu kali. Pada saat ini pula salah seorang orang tua thullab mengucapkan ijab, yaitu tiang serah anak tiang kepelungguh untuk belajar di ma'had diajar ilmu agama, tiang serah mayung sebungkam, artinya mayung itu kuserahkan sepenuhnya pada Tuan Guru untuk dijadikan apa saja yang penting saya akan terima manfaatnya. tuan guru (kabul), kuterima mudah-mudahanjari anak sibacu alim, saleh mau ilmu berkat dunia akhirat, artinya diterima dengan iringan doa mudahmudahan menjadi anak yang taat, alim, saleh mendapat ilmu yang bermanfaat dunia dan akhirat.

Upacara zikaral hauliyah didahului dengan menghilangkan sesuatu sifat (akhlak) yang terdapat dalam diri seseorang calon thullab dan thullabah yang mungkin akan mengganggu penerimaan ilmu pengetahuan yang baru, yaitu ilmu pengetahuan keislaman yang hakikatnya merupakan lambang harapan agar mereka mudah menerima ilmu pengetahun yang mulia.

Telah dikemukakan bahwa semua pendidikan madrasah juga merupakan ma'had yang secara tidak langsung membina pengkaderan ulama walaupun dalam kapasitas yang terbatas, namun pendidikan yang dikemukakan disini adalah pendidikan kepesatrenan yang dikenal dengan Ma'had Ali, yaitu Ma'had Darul Quran wal Hadis merupakan lembaga pengkaderan ulama. 
Dalam ma'had terdapat dua pembinaan atau pengajian, yaitu pengajian umum dan pengajian khusus. Pengajian umum seperti telah dikemukan merupakan pengajian yang wajib diikuti oleh semua santri, dilakukan di Masjid Darul Quran Wal hadis padajam 7.30-9.30 Wita dengan jadwal kegiatan sebagai berikut;

Sabtu $=$ MengajikitabSamailulRasul.

Ahad $=$ Hadis Al-Azkar.

Senin $\quad=$ Tafsir Jalalain.

Selasa $=$ Tasauf

Rabu $\quad=$ Fiqhi

Kamis $=$ Tafsir, sedangkan pada hari Jum'at adalah hari libur.

Pengajian Khusus yang dikenal dengan ma'had 'ali, ma'had ini menggunakan referensi kitab klasik yang populer disebut kitab kuning merupakan bahan pembelajaran yang secara formal disajikan oleh Tuan Guru pada thullab dan thullabah terutama kitab yang disusun oleh ulama Syafiiyah.

Kitab klasik tersebut menurut Dhofier diklasifikasi dalam 8 kelompok; yaitu 1) Nahwu (sintaksis dan Saraf) atau morfologi. 2) Fiqhi. 3) Usui Fiqhi. 4) Tafsir. 5) Hadis. 6) Tauhid. 7) tasauf dan Etika. 8) Cabang-cabang lain seperti tarih dan balagah. ( 1984 : 50)

Kitab tersebut meliputi teks yang sangat pendek sampai yang terdiri dari jilid tebal mengenai hadis, tafsir, fiqhi, usul fiqhi dan tasauf yang kesemuanya itu dibagi dalam tiga kelompok yaitu kitab dasar, tingkat menengah dan tingkat kitab-kitab besar. Kitab klasik biasa ditulis dalam Bahasa Arab, Melayu, Melayu Jawa, Melayu Indonesia, Sunda, dan di Pulau Lombok dengan Bahasa Sasak. Banyak tulisan Al Magfurullah Maulana Syaikh TGKH. Muhamad Zainuddin Abdul Madjid dalam Bahasa Sasak. Tulisan kitab klasik adalah tulisan tidak bertanda baca (tidak berharakat/ syakl) karena itu biasa juga dikenal dengan kitab gundul. Umumnya kitab dicetak di atas kertas berwarna kekuning-kuningan. Dulu lembaran-lembaran terlepas (tidak dijilid) untuk memudahkan mengambil bagian-bagiannya kalau diperlukan atau untuk memudahkan dibawa kalau menyajikan dan mengikuti pengajian, juga karena pada saat itu belum ada penjilidan, tetapi sekarang semua kitab yang dipakai sudah merupakan suatu kitab yang utuh (terjilid) dengan rapi.

Konsep tersebut menunjukan bahwa di pondok pesantren menggunakan kitab klasik berdasarkan kurikulum yang dibuat oleh pesantren, demikian halnya di Pondok Pesantren Syaikh Zainuddin NW menggunakan kitab klasik yang dijadikan acuan dan dikaji dalam pengajian umum, kitab 
tersebut adalah; Kitabussa 'adah, Husunul Hamidiyah, Kifayatul Awwam (tauhid). Iqra'Batungompal, tafsir Jalalain/Shawi, tafsir Ibnu Katsir, Al maragi (tafsir). Shaheh Bukhari/Muslim, Riadushalihin, Bugul Muram/Ibanatul Ahkam, Al-Azkarunnawaw (hadis). Goyatuttalibin,FathulQarib,Safinatunnajah/ Khasyifatusyaja, I'anatuttalibin, Anwarul Masalik, kifayatul Akhyar (fiqhi). Waraqat, Idhahul Qawaidul Fiqhiyyah (usul fiqhi). Matan Ajjurumiyah, Nahwu Wadih, Syarah Dahlan, Mutammimah/Kawakib Addurriyah, Alfiah Ibnu Malik/ Ibnu Akil (Nahwu). Amsilatul Jadidah, Matnul Bina' Wal Asas, Kalilani Izzi (Sharaf). Qawa'idullugah Al-Arabiyyah, Jawahirul Maknun (balagah). Tarikh Tasyri' (tarikh). Idhahul Mubham (Mantiq). Tuhfatuzzainiyyah, Nahdlatuzzainiyyah, Matnurrahbiyyah, Syarah Asy-Syantsuri (faraid). Minhatul Mugits, RafulAstar, Tagriratussaniyyah (mustalahul hadis). Qaulul Munir, Faidul Khabir (Usui tafsir). Mukhtashar Ilmu Falaq Wal Miqat (ilmu falaq). Mukhtarusysyafi (urud). Akhlaqul Banin, Ta'lim Muta'allim, Minhajul Abidin/ Sirajuttalibin, Ihya'ulumuddin, Nashoihudiniyyah (Akhlak/tasauf. Dan masih banyak buku yang tidak sempat dimuat dalam tulisan ini dan buku-buku tersebut menghiasi lemari buku perpustakaan pondok pesantren Anjani.

Pada pondok pesantren tradisional menggunakan kitab klasik yang dikarang oleh ulama yang mengagumi faham sesuatu majhab. Demkian pula yang terjadi pada pondok pesantren Syaikh Zainuddin NW Anjani mereka menggunakan kitab mazhab syafii karena pendiri pondok pesantren ini berfaham Ahlusunnah Wal Jamaah.

Telah dikemukakan bahwa pondok pesatren Syaikh Zainuddin NW Anjani sejak berdirinya yang pertama dibina adalah Ma'had Ali Darul Quran Wal hadis, 26 Desember 1998/15 Ramadan 1419 H.. Pengajian dilaksanakan setiap hari padajam 09.45-13.00 setelah selesai pengajian umum, dimulai padajam 09.45 mereka melanjutkan ma'had Ali.

Terdapat 16 orang Tuan Guru yang membina Ma'had Ali secara khusus pembinaan dengan mengacu pada kitab seperti telah dikemukakan sesuai dengan disiplin ilmunya masing-masing, yaitu;

1). TGKH. Muhamad Ruslan Zein, membina ilmu tafsir, balagah dan tauhid.

2). TGKH. Lalu Anas Hasri, membina ilmu arud, ilmu falaq dan balagah.

3). TGKH. Zaini Abdul Hanan Lc, membina ilmu tafsir, mantiq dan faraid.

4). TGKH. Habib Tantawi, membina ilmu nahwu/syaraf dan faraid.

5). TGKH. Muhamad Yasin, membina ilmu fiqhi dan nahwu.

6). TGKH. Muhamad Hilmi Najamuddin, membina ilmu akhlak, tasauf dan tafsir.

7). TGKH.Muhamad Natsir, membina ilmu mantik

8). TGKH. Zainal Arifin Munir Lc, membina ilmu syaraf, dan qawaidul fiqhi 9). TGKH. Mukhsin Muhyiddin, membina ilmu tarikh dan ilmu syaraf.

10). TGKH. Izuddin Habib, membina ilmu Syaraf. 
11). TGKH. Salehuddin Lc, membina ilmu hadis dan ilmu mustalhulhadis.

12). Ustaz Drs. Mustamihuddin Ibrahim SH, membina ilmu Hadis.

13). TGKH. Arifin Mahdi, membina ilmu nahwu

14). TGKH. Hamzah Abdul Halim, membina ilmu fiqhi.

15). TGKH. Drs. Abdul Barri, membina ilmu fiqhi, nahwu dan ilmu tauhid.

16). TGKH. Abdul Hayyi Zainur.

Untuk menentukan seseorang diberi gelar Tuan Guru apa bila telah menunaikan ibadah Haji, seorang tetap berpredikat ustaz selama dia belum melaksanakan ibdah haji walaupun kualitas ilmunya sama dengan kualitas ilmu para Tuan Guru.

\section{V . P E N U T U P}

\section{A. Kesimpulan.}

Pondok Pesantren Syaikh Zainuddin Nahdlatul Wathan adalah pecahan dari Pondok Pesantren Darnnadlatain Nahdlatul Wathan Pancor. Hal ini terjadi akibat konflik intern antara Ummi Hj. Sitti Rauhun dengan Ummi Hj. Sitti Raihanun dua putri Al Magfurullah Maulana Syaikh TGKH. Muhammad Zainuddin Abdul Madjid, sehingga Ummi Hj.Sitti Raihanun mendirikan Pondok Pesantren Syaikh Zainuddin Nahdlatul Wathan di Anjani Kecamatan Suralaga Kabupeten Lombok Timur.

Di pondok pesantren ini terdapat lembaga pendidikan klasikal (sekolah) dan pendidikan kepesantrenan (ma 'had dan $\boldsymbol{m a}$ 'had Ali). Ma 'had disebut pengajian umum dan dan $\boldsymbol{M a}$ 'had $\boldsymbol{A l i}$ disebut pengajian khusus.

Pembelajaran berlangsung sesuai dengan yang diharapakan karena dalam lembaga ini interaksi antara thullab dengan thullab, thullab dengan Tuan Guru berlangsung atas dasar keikhlasan sehingga menimbulkan rasa penghormatan, saling asah, asih dan asuh.

Proses pembelajaran menggunakan kurikulum khusus pondok pesantren, menggunakan sistem halaqah dengan metode sorogan, bandongan dan wetonan. dengan kitab klasik sebagai acuannya.

Komunitas Sasak menganggap Tuan Guru, adalah segalanya karena ilmu pengetahuan yang mereka miliki, apa yang diucapkan oleh Tuan Guru dianggap fatwah yang harus ditaati dan dilaksanakan. Oleh sebab itu Komunitas Sasak mengharapkan kriteria ulama seperti sosok Al Magfurullah Maulana Syaikh TGKH. Muhamad Zainuddin Abdul Madjid dan para muridnya patut diteladani.

Keberadaan pondok pesantren membawa keberuntungan bagi masyarakat sekitar, karena pada Tuan Guru, ustaz dan santri tempat mereka menggantungkan harapan (minta pertolongan) dalam hal yang berhubungan dengan masalah agama dan upacara keagamaan. 


\section{B. Saran.}

Melihat kenyataan pada Pondok Pesantren Syaikh Zainuddin Nahdlatul Wathan, adalah pondok pesantren baru dibanding dengan Pondok Pesantren Darunnahdlatain Nahdatul Wathan Pancor, tetapi dalam perkembangannya cukup memberikan harapan. Hanya pondok pesantren ini masih dalam taraf pembenahan di berbagai aspek, terutama masih dalam menyelesaikan pembangunan fisik termasuk pembebasan tanah yang masih memerlukan dana miliaran rupiah. Oleh sebab itu di dalam membantu mencerdaskan anak bangsa, kiranya pemerintah terutama pemerintah daerah Kabupaten Lombok Timur mempertimbangkan memberi bantuan untuk meringankan beban yang dihadapi Yayasan dan panitia pembangunan Pondok Pesantren Syaikh Zainuddin Nahdlatul Wathan Anjani agar mampu melaksanakan amanah yang dibebankan kepada mereka.

\section{DAFTAR PUSTAKA}

Abidin, Zainal, Khulasyah Tarikh Nahdla tul Wathan. Pancor :1976

Badan Pusat Statistik, Lombok Timur Dalam Angka, Badan Pusat Statistik Kabupaten Lombok Timur, Mataram, Tahun 2003

Dhofier, Zamakh Syari, Tradisi Pesantren Studi Tentang Pandangan Hidup Kiai, LP3S, Jakarta Tahun 1982

Junaidi, Dinamika Kehidupan Beagama di Pondok Pesantren Darunnadlatain Nahdlatul Wathan (NW) Pancor Kabupaten Lombok Timur Nusa Tenggara Barat, (thesis), PPS Universitas Negeri Yogyakarta,2000.

Moh. Irfan,H.Drs.Sh.M.Pd, Pola Pemberdayan Masyarakat Melalui Pondok Pesantren, Depaf RI. Direktorat Jenderal Kelembagaan Agama Islam. Direktorat Pendidikan Keagamaan dan Pondok Pesantren, Proyek Peningkatan Pendidikan Luar Sekolah Pondok Pesantren, Jakarta, 2003.

Muhaimin.Tajab dan Abd Mujib, Dimensi-Dimensi Study Islam, Karya Aditama, Surabaya, 1994.

Raharjo, Dawam, Pergulatan Dunia Pesantren Membangun Dari Bawah, P3M, Jakarta, 1985.

Shiddiqi, Nourouzzaman, Jeram-jeram Peradaban Muslim, Pustaka Pelajar, Yogyakarta, 1996.

Zaini, Wahid.A, Dunia Pemikiran Kaum Santri, LKPSM, Yogyakarta, 1995. 